\title{
Granitoid source and orogen types
}

TAO WANG ${ }^{1,2}$, XIAOXIA WANG ${ }^{3}$, YING TONG ${ }^{2}$, HE HUANG $^{2}$, CHAOYANG WANG ${ }^{2}$, JIANJUN ZHANG ${ }^{2}$, LEI GUO $^{1}$, SHAN LI ${ }^{2}$, LEI ZHANG ${ }^{2}$

${ }^{1}$ Beijing SHRIMP Center, Beijing 100037, China

${ }^{2}$ Institute of Geology, CAGS, Beijing 100037, China

${ }^{3}$ MLR Key Laboratory of Metallogeny and Mineral Assessment, Institute of Mineral Resources, CAGS, Beijing 100037, China

Granitoids are widely exposed in orogens that are generally grouped as accretionary and collisional. However, the relationships between granitoid source and orogen types have not been well understood. This study attempts to discuss this problem by comparing $\mathrm{Nd}-\mathrm{Hf}$ isotopic mapping of granitoids from the Central Asian Orogenic Belt (CAOB) and the Appalachian orogen (AO), two typical worlds' accretionary orogens, as well as the Qinling-Dabie orogen (QDO), a typical collisional orogen. Phanerozoic (500-200 $\mathrm{Ma})$ granitoids of the CAOB are mostly I- and A-type. Their $\mathrm{Nd}-\mathrm{Hf}$ isotopic mapping determines five source provinces: very juvenile (model ages $<0.8 \mathrm{Ga}$ ), juvenile $(<1.0 \mathrm{Ga}$ ), less old $(1.0-1.6 \mathrm{Ga}<)$, old $(1.6-2.0 \mathrm{Ga})$ and very old $(>2.0 \mathrm{Ga})$. Juvenile provinces $(<1 . \mathrm{Ga})$ occupy more than $50 \%$ or even $60 \%$ areas of the studied areas. The juvenile source can be derived from subducted oceanic rocks, accretionary wedges, intra-oceanic arcs, oceanic plate sedimentary units. A preliminary analysis of the isotopic compositions of the Phanerozoic granitoids from the Newfoundland Appalachians display that the similar juvenile provinces $(<1.0 \mathrm{Ga})$ occupies about $20-40 \%$ of the areas. Similar isotopic mapping in other Paleozoic orogens reveals much less $(<$ $10 \%)$ juvenile provinces $(<1.0 \mathrm{Ga})$, such as the QDO in the central China. These display the relationship of granitoid source and orogen types. Based on general classification and typology such as I-, S-, and A- types, granitoids can be further classified by (juvenile to ancient) source (such as by $\mathrm{Nd}$, Hf isotopes). Furthermore, regional mapping of granitoid isotopes can image source provinces in deep crust. It is helpful for better understanding the relationship of granitoid source and orogen types. Much more juvenile source provinces of granitoids characterized the typical accretionary orogens or end-member of accretionary orogens such as the CAOB. Slightly more juvenile provinces characterized general accretionary orogens such as the $\mathrm{AO}$ and less juvenile province collisional orogens (such as the QDO). Thus, it may be possible to establish criteria to (semi-) quantitatively describe orogen types and development through evaluation of the relative proportions of juvenile vs. reworked crust. 